\title{
Law: A Map of Misreading. Toward a Postmodern Conception of Law
}

\author{
BoAventura De Sousa Santos*
}

\section{INTRODUCTION}

In Thus Spoke Zarathustra Nietzsche announced that the spirit has undergone three metamorphoses. ${ }^{1}$ In the first one the spirit becomes a camel; then the camel becomes a lion; and finally the lion becomes a child. While a camel, the spirit allows itself to be loaded with any values or beliefs humanity wants to load it with. But while speeding into the desert the spirit undergoes a second metamorphosis and the camel becomes a lion. The lion is the animal in revolt against the values and beliefs it was loaded with before. The lion is the spirit of negativity that substitutes 'I will' for 'thou shalt'. But because it merely acts against, the lion is a purely negative being, incapable of creating new values to replace the old ones. In order to take this further step the spirit must undergo a third metamorphosis through which the lion becomes a child. As a child the spirit is innocent and forgetting, it is a new beginning, the creation of new - values. Only then will the spirit will its own will and conquer its own world.

I would like to suggest that law has also undergone three metamorphoses in the modern era. However, the sequence of the steps has been reversed. In the seventeenth and eighteenth centuries law started out as a child. The new theories of natural law and the liberal political philosophy were a magnificent new creation of values and beliefs that testified to the emergence and consolidation of bourgeois society. But as the nineteenth century wore on, the law became the lion of negativity. It was the time when law was resisting against the demands which the social question had given rise to and which were being pressed into the political agenda by emergent social and political forces. In the twentieth century, and particularly after the Second World War, the law underwent a third metamorphosis. It gave up resistance in docile submission to the whole range of values and beliefs - sometimes complementary, sometimes contradictory - that the different social and political

*Department of Sociology, School of Economics, University of Coimbra, 3000 Coimbra, Portugal.

This paper is the Journal of Law and Society Annual Lecture, delivered at University College, Cardiff on 5 March 1987. I would like to thank those who in different ways helped me to draw this map of the law. Special thanks are due to Philip Thomas, António Gama, Maria Irene Ramalho, Maria Manuel Marques, Kristin Bumiller, Peter Fitzpatrick and Leonor Marinho Dias. 
forces imposed upon it. In sum, law became a camel, and the welfare state is the most salient feature of this process of 'camelisation' of the law.

As we approach the end of the century and start thinking fin de siècle, many voices rise against the camelisation of the law. Habermas has spoken of the excessive colonisation of the life-world (Lebenswelt) by law. ${ }^{2}$ Nonet and Selznick plead for a responsive $\mathrm{law}^{3}$ and Teubner for a reflexive law. ${ }^{4}$ In all these theories there is a call for a new metamorphosis of the law, one that will bring it back again to its proper and natural limits, whatever they may be.

In this paper I will not be interested in the nature or even the possibility of such a metamorphosis. If it can be said that numbers - like reason - play tricks on us, it may well be that the three metamorphoses having already taken place, the magical number three will not allow for a fourth metamorphosis. Or it may be, in Nietzschian terms, that such a metamorphosis will not engender a law with a new spirit but rather a law without a spirit, that is, the end of law, be it a rhetorical end, as in O'Hagan's The End of Law?, 5 or a literal end as in Foucault's denounced substitution of disciplinary power for juridical power. ${ }^{6}$

In this paper I am concerned rather with a preliminary task. My starting point is that the camelisation of law has brought with it the camelisation of the sociology of law and, accordingly, that before the 'decamelisation' of the law may be attempted, a full decamelisation of the sociology of law must be accomplished. What are the symptoms of the camelisation of the sociology of law? Probably better than anyone else, Richard Abel has denounced that:

... social studies of law have reached a critical point in their development. The original paradigm is exhausted. Until new ones are constructed, scholarship will be condemned to spin its wheels, adding minor refinements to accepted truths, repeating conventional arguments in unresolvable debates. ${ }^{?}$

Two major factors are responsible for this impasse. The first one, identified by Abel, is that:

... sociological studies have borrowed most of their research questions from the object of study - the legal system (whose problems are defined by legal officials) - and from those who studied it first - legal scholars (themselves lawyers). ${ }^{8}$

The second factor, recently emphasised by David Nelken, is that the law and society have been conceived in the conventional paradigm, as two separate and distinct realities or entities which are then juxtaposed in order to investigate the extent to which they correspond or do not correspond. The most important 'exemplars' of sociological research on law have been developed from this conception (the study of the relations between law in books and law in action and the study of the impact of society on law or, inversely, the study of the impact of law in society). ${ }^{9}$

In recent years there have been some attempts away from this theoretical gulag: I will mention three of them. The first one is the research on legal pluralism in contemporary society which challenges the conventional paradigm in two ways. On the one hand, while legal officials and legal scholars assume the state monopoly of legal production, research on legal pluralism maintains the existence and circulation in society of different legal systems, the 
state legal system being one of them, even if the most important one. On the other hand, such a broader conception of law indicates a more complex relation between law and society, since there is not one single law but a network of laws that must be matched with society. ${ }^{10}$ The second new direction in socio-legal studies is the whole movement (and stasis) of critical legal studies in the United States of America and the United Kingdom as well as in France and Mexico or in Portugal and Italy. By transforming legal science and legal scholarship into an object of scientific research, critical legal studies carve out an autonomous field of enquiry and thus maintain "a critical distance from the self-conceptions of legal professionals", as Alan Hunt has put it. ${ }^{11}$ The third attempt away from the conventional paradigm is the research on the obstacles or constraints limiting both the impact of law on society and the impact of society on law and, more generally, the research on the lack of correspondence between forms of law and social structures of which Stuart Henry's recent book on private justice is a good example. ${ }^{12}$

I am not going to dwell on any of these lines of research. I will only mention some of their shortcomings and the questions they leave unanswered. First, if we substitute the soft law of legal pluralism for the hard law of legal scholarship, where does pluralism end? What is law, and where is it? Secondly, in spite of their proclaimed distances in relation to conventional legal science, all these lines of research share its exclusive concern with the normative content of law. Normativity is surely the heavy reality of the law. But law is also imagination, representation, and description of reality. Where, then, is the non-normative dimension of the normative? How is it constructed? Thirdly, it is important to show that the correspondence between law and society is far more complex than previously admitted, or even that there is no correspondence. But these findings seem, then, to assume that the only possible relation between law and society is that of correspondence or lack of correspondence. This assumption leaves unanswered or even suppressed the question of whether law and society may relate other than through correspondence or lack of correspondence.

I have attempted to answer the first question elsewhere. ${ }^{13}$ In this paper I will try to concentrate on the second and third questions. In order to do that, allow me to take you to some exotic places, both real and symbolic. The title of this paper is taken from the title of a book by Harold Bloom, one of the most creative literary critics of our time. ${ }^{14}$ According to his theory of poetic creation, in order to be original each poem must misread the poetic tradition which comes down to it through the generations and generations of poems and poets that preceded it. Poets suffer from the anxiety of influence and poetry is always the result of the poet's attempt to deny it. Poets overcome the anxiety of influence by misreading (or distorting) poetic reality.

I chose this title for two reasons. Firstly, because I think that law, like poems, must misread or distort reality and for similar reasons. Poems misread in order to establish their originality, while laws misread in order to establish their exclusivity. Irrespective of the plurality of normative orders we detect in society, each of them, taken separately, aspires to be exclusive, to have the 
monopoly of the regulation and control of social action within its legal territory. This is most patently the case with state laws, be they labour laws, criminal laws, or administrative laws. In order to operate adequately, a given labour law, for instance, must not only negate the existence of other normative orders or informal laws (such as factory codes, production of customary laws, etc.) that might interfere in its realm of application, but also revoke all the state labour laws that have previously regulated the same labour relations. This is, as we well know, a double misreading of reality. On the one hand, as legal pluralist research tells us, other normative orders do operate and are effective in the same legal territory. On the other hand, since law and society are mutually constitutive, the previous labour laws, once revoked, nevertheless leave their imprint on the labour relations they used to regulate. Though revoked, they remain present in the memories of things and people. Legal revocation is not social eradication.

This misreading of reality is not chaotic. It occurs through determinate and determinable mechanisms. Moreover, the distortion of reality which it implies does not automatically mean a distortion of truth. We have assumed too lightly in the past that truth and reality are one and the same thing. Closer attention to the pragmatics of legality may force us to conclude that such an assumption is an illusion produced by the correspondence paradigm concerning the relations between law and society. Now, here lies the second reason for the title of my paper. In my view, the relations law entertains with social reality are much similar to those between maps and spatial reality. Indeed, laws are maps; written laws are cartographic maps; customary, informal laws are mental maps. This is a strong metaphor and as such it will be taken literally, hence the subtitle of this paper might very well be: "on taking metaphors literally". In the following section I will draw extensively on the work of cartographers and I will try to show how much sociology of law may learn from cartography. I will deal with the structural features of maps and map-making as well as with the phenomenology of using maps.

\section{UNDERSTANDING MAPS}

The main structural feature of maps is that in order to fulfill their function they inevitably distort reality. The great Argentinian writer Jorge Luis Borges has told us the story of the emperor who ordered the production of an exact map of his empire. He insisted that the map should be exact to the most minute detail. The best cartographers of the time were engaged in this important project. Eventually, they produced the map and, indeed, it could not possibly be more exact, as it coincided point by point with the empire. However, to their frustration, it was not a very practical map, since it was of the same size as the empire. ${ }^{15}$

To be practical a map cannot coincide point by point with reality. However, the distortion of reality thus produced will not automatically involve the distortion of truth, if the mechanisms by which the distortion of reality is accomplished are known and can be controlled. And, indeed, that is the case. 
Maps distort reality through three specific mechanisms and since they are used systematically they become intrinsic or structural attributes of any map. Such mechanisms are: scale, projection, and symbolisation. They are autonomous mechanisms that involve different procedures and require separate decisions. But they are also interdependent. As the American cartographer Mark Monmonier put it:

... all advantages and limitations of maps derive from the degree to which maps reduce and generalise reality, compress or expand shapes and distances and portray selected phenomena with signs that communicate without necessarily resembling visible or invisible characteristics of the landscapes. The three elements of a map are interdependent. Scale influences the amount of detail that can be shown and determines whether or not a particular kind of symbol will be visually effective. ${ }^{16}$

Maps should be convenient to use. There is thus a permanent tension in maps between representation and orientation. These are contradictory claims and maps are always unstable compromises between them. Too much representation may hinder orientation, as we saw in Borges's map. Inversely, a very accurate orientation may result from a rather poor and elementary representation of reality. When you are invited to a party in a house whose location you do not know, the host will probably draw a map which will be very effective in orienting you though very inaccurate in representing the features of the environment along the way to your destination. One more example: some of you may have seen medieval portolans, those maps of ports and coasts well-renowned in the Middle Ages which, though very poor as far as representation of the globe goes, were very effective in orienting navigators . at sea. ${ }^{17}$ There are maps that solve the tension between representation and orientation in favour of representation. These I would call, borrowing from French cartography, image maps. Other maps solve the tension in favour of orientation. These are instrumental maps. ${ }^{18}$

I would like to suggest that this dialectic of representation and orientation applies to law as much as it applies to maps. In the analysis of the relations between law and society we should substitute the complex paradigm of scale/ projection/symbolisation for the simple paradigm of correspondence/noncorrespondence. In the following I will linger on maps a little while to analyse in more detail each one of the procedures through which maps distort reality. In the process I hope to interest you in the fascinating world of maps. As Josef Konwitz has said, "It is a supreme irony that maps, though they are one of the most common cultural metaphors, are still far from occupying the place they deserve in the history of mentalities." 19

The first major mechanism of representation/distortion of reality in maps is scale. Scale, as Monmonier has defined it, "is the ratio of distance on the map to the corresponding distance on the ground". ${ }^{20}$ Scale involves, then, a decision on more or less detail. "Since large-scale maps represent less land on a given size sheet of paper than do small-scale maps, large-scale maps can present more detail." 21 Since maps are "a miniaturised version" of reality, ${ }^{22}$ map-making involves the filtering of details, "the selection of both meaningful details and relevant features". ${ }^{23}$ As Muehrcke put it, 
"what makes a map so useful is its genious of omission. It is reality uncluttered, pared down to its essence, stripped of all but the essentials." 24 One easily understands that the decision on scale conditions the decision on the use of the map, and vice-versa. "Small-scale maps are not intended to permit accurate measurements of the width of roads, streams, etc., but rather to show with reasonable accuracy the relative positions of these and other features." 25

Geography, which shares with cartography the concern for spaces and spatial relations, has also contributed important insights on scales, both scales of analysis and scales of action. As to the former, there are phenomena that can only be represented on a small scale, such as climate, while others, like erosion, for instance, can only be represented on a large scale. ${ }^{26}$ This means that the differences in scales are not simply quantitative but they are also qualitative differences. A given phenomenon can only be represented on a given scale. To change the scale implies change of the phenomenon. Each scale reveals a phenomenon and distorts or hides others. As in nuclear physics, the scale creates the phenomenon. Some of the fallacious correlations in geography derive from the superimposition of phenomena created and analysed on different scales. The scale is "a coherent forgetting" that must be carried out coherently. ${ }^{27}$

Mediating between intention and action, scale applies also to social action. Urban planners as well as military chiefs, administrators, business executives, legislators, judges, and lawyers define strategies on a small scale and decide day-to-day tactics on a large scale. Power represents social and physical reality on a scale chosen for its capacity to create those phenomena that maximise the conditions for the reproduction of power. The distortion and concealment of reality is thus a presupposition of the exercise of power.

The second mechanism of representation/distortion of reality is projection. To be useful maps must be easily carried about and stored. Flat maps can be rolled and folded. It is by means of projection that the curved surfaces of the earth are transformed into planes. The most convenient transformation cannot yield flat maps without distorting shapes and distance relationships. I am not going to bother you with the specifics of projections, the different types of projection and the distribution and degrees of distortion characteristic of each of them. ${ }^{28}$ I will only make a few general remarks that are relevant to my argument. The first remark is that projections do not distort reality at random. Each type of projection creates a field of representation within which forms and degrees of distortion are unequally but determinably distributed. For instance, some projections distort the equatorial regions more than the polar regions, while others do the opposite. Moreover, the different projections distort the different features of the space differently. Some projections (called the conformal projections) preserve areas but distort angles and shapes and directions, while other projections (called equivalent projections) do the inverse. We cannot get the same degree of accuracy in the representation of all the different features and whatever we do to increase the accuracy in the representation of one given feature will increase the distortion in the 
representation of some other feature. It is very much like the uncertainty principle of Heisenberg in quantum physics, according to which we cannot measure the velocity and the position of the particles simultaneously and with the same degree of precision and whatever we do to increase accuracy in determining the position will distort the measurement of velocity.

Every map projection is thus a compromise. The decision on which kind of distortion to prefer is conditioned by precise technical factors but it is also based on the ideology of the cartographer and on the specific use intended for the map. For instance, during the cold war the western mass media used to show the Soviet Union on a world map designed according to the cylindrical projection of Mercator. Since this kind of projection exaggerates the areas in high and median latitudes in detriment of those in inter-tropical latitudes, such a map would inflate the size of the Soviet Union, thus dramatising the extent of the communist threat. ${ }^{29}$

The second remark on projection is that each map, each historical period or each cultural tradition of map-making has a centre, a fixed point, a physic or symbolic space in a privileged position around which the diversity, the direction, and the meaning of other spaces is organised. For instance, medieval maps used to put a religious site at the centre - Jerusalem in the European maps, Mecca in the Arab maps. ${ }^{30}$ The same happens with mental maps, that is, with the cognitive visual images we have of the world around us. As Muehrcke said, "most of our mental maps would emphasise our own neighbourhood, with its environments assuming less significance." 31

Symbolisation is the third mechanism of map representation/distortion of reality. It refers to the representation of selected features and details of reality in graphic symbols. Without signs the map will be as unusable as Borges's map. Such is the case of the Bellman's map in Lewis Carroll's Hunting of the Snark. ${ }^{32}$ You may remember the verses:

... One could see he was wise,

the moment one looked in his face!

He had brought a large map representing the sea, without the least vestige of land: And the crew were much pleased when they found it to be. A map they could all understand.

"What's the good of Mercator's North Poles and Equators,

Tropics, Zones and Meridian Lines?"

So the Bellman would cry: and the crew would reply.

"They are merely conventional signs!"

"Other map; are such shapes, with their islands and capes!

But we've got our brave Captain to thank"

(So the crew would protest)

"that he's brought us the best -

A perfect and absolute blank!" 33

Cartographic language is a fascinating theme and semiotics has provided its research with new analytical tools. The sign systems have evolved over time and still today different systems may be chosen according to the specific 
cultural context of the map-maker or according the purposes of the maps. In a recent book on this topic, J. S. Keates, drawing from semiotics, distinguishes between iconic signs and conventional signs. ${ }^{34}$ Iconic signs are naturalistic signs that establish a relation of likeness with the reality represented (for instance, a bunch of trees to designate a forest) while conventional signs are far more arbitrary. "Convention holds that certain types of symbols are appropriate for certain types of phenomena" - for instance, linear symbols for roads and boundaries and graduated circles for cities and towns. ${ }^{35}$ If we look at the historical record it will show that the sign systems used in maps were initially more naturalistic and gradually became more conventional. ${ }^{36}$ But even today, according to many circumstances, maps may be more figurative or more abstract; they may rely on emotive/expressive signs or on referential/ cognitive signs; they may be more readable or more visible. ${ }^{37}$

You may be surprised with this digression on maps. Clifford Geertz said that law was a way of imagining the real. ${ }^{38} \mathrm{My}$ argument is that there are many unresolved problems in the sociological study of the law that may be solved by comparing law with other ways of imagining the real. Maps are one such way. There are, in fact, striking similarities between laws and maps - both concerning their structural features and their use patterns. Obviously, laws are maps only in the metaphorical sense. But, as rhetoric also teaches us, the repeated use of a metaphor over a long period of time may gradually transform the metaphorical description into a literal description. ${ }^{39}$ Today laws are maps in a metaphorical sense. Tomorrow they may be maps in a literal sense.

\section{A SYMBOLIC CARTOGRAPHY OF LAW}

I will now present the outline of what I would call a symbolic cartography of law. I will try to show that the national (and the international) territory consists of several social spaces which, though autonomous, interrelate in different ways. Within each social space and across spaces different kinds of juridical capital circulate: nationalised or state juridical capitals and private juridical capitals, sacred and profane juridical capitals, and so on. Each kind of juridical capital prompts a specific kind of actions and symbolic universes. In the modern era law has become the privileged way of imagining, representing, and distorting, that is to say, of mapping these social spaces and the capitals, the actions and symbolic universes that animate or activate them. In order to illustrate this point I will draw on theoretical sociology of law as well as on my own empirical research conducted in Portugal, in Brazil, and in the Cape Verde Islands. The research in Portugal deals with the contradictions between democratic legality and revolutionary legality during the revolutionary crisis of 1974-75, in the aftermath of the fall of the dictatorial regime that ruled the country for almost fifty years. ${ }^{40}$ The research in Brazil, conducted in 1980 in the north-eastern city of Recife, deals with the social and legal battles of squatter settlers against the state and private landowners to 
obtain a legal title over the land they had invaded and upon which they had built their shacks and organised their urban lives. ${ }^{41}$ The research in the Cape Verde Islands, conducted in 1984 and 1985, is concerned with the popular courts that have been created by the state since independence from Portuguese colonialism in 1975. These are non-professional courts organised on a residential basis and with jurisdiction over small civil disputes and petty crimes. $^{42}$

\section{Law and Scale}

One of the main reasons for recommending the symbolic cartography of law is its ability to analyse the effect of scale on the structure and use of law. The modern state is based on the assumption that law operates on a single scale, the scale of the state. For a long time the sociology of law accepted this assumption uncritically. In recent times the research on legal pluralism has drawn our attention to forms of local legality in rural areas, in marginalised urban sectors, in churches, in sports, in the professions. These are forms of infra-state laws, most of them informal, unofficial, more or less customary. Most recently, the research on international economic exchanges has revealed the emergence of a new lex mercatoria, an international legal space in which different types of economic agents operate, whose behaviour is regulated by new international rules and contractual relations established by dominant multinational corporations, international banks or international associations dominated by both. ${ }^{43}$ Transnational capital has thus created a transnational legal space, a supra-state legality, a world law. This legality is in general very informal. Based on dominant practices, that is, on the practices of dominant agents, it only makes sense to consider this world legality customary if we allow for the fact that new practices (for instance, a new type of contract invented by a multinational corporation) often create what we might call instant customs. Nor does it make much sense to consider it unofficial, since this world legality develops forms of immunity vis-à-vis both the national state law and the public international law. ${ }^{44}$

The legal developments reveal the existence of three different legal spaces and their correspondent forms of law: local, national and world legality. It is rather unsatisfactory to distinguish these legal orders by their respective objects of regulation because often they regulate or seem to regulate the same kind of social action. Local law is a large-scale legality. Nation state law is a medium-scale legality. World law is a small-scale legality. This concept has broad implications. First, it means that, since scale creates the phenomenon, the different forms of law create different legal objects upon eventually the same social objects. They use different criteria to determine the meaningful details and the relevant features of the activity to be regulated. They establish different networks of facts. In sum, they create different legal realities. Let us take the example of the labour conflict. The factory code, that is, the private justice of the workplace, as a form of local legality, regulates the relations in production in great detail in order to maintain workplace discipline, to prevent labour conflicts, to reduce their scope whenever they occur and 
eventually to settle them. The labour conflict is the nuclear object of the factory code because it confirms a contrario the continuity of the relations in production, which are the raison d'être of the factory code. In the wider context of the national state labour law, the labour conflict is only a dimension, however important, of industrial relations. It is part of a broader network of social, political and economic facts in which we easily identify, among others, political stability, inflation rate, income policy and relations of power among labour unions, business, and government. In the still wider context of the world legality of international franchising, or of international subcontracting, the labour conflict becomes a minute detail in international economic relations hardly worth mentioning.

Thus, the different legal orders operating on different scales translate the same social objects into different legal objects. However, in real socio-legal life the different legal scales do not exist in isolation but rather interact in different ways. Let us continue with our example and hypothesise that a labour conflict occurs in a Portuguese garment factory subcontracted by a multinational corporation. ${ }^{45}$ In such a case the regulatory purposes of the three legal scales converge in the same social event. This creates the illusion that the three legal objects can be superimposed. In fact, they do not coincide; nor do their 'root images' of law and the social and legal struggles they legitimate coincide. Workers and sometimes the employer tend to have a large-scale view of the conflict, full of details and relevant features, a concept moulded by local legality. Union leaders and sometimes the employer tend to see the conflict as a crisis in a process of continuous industrial relations. Their view is predominantly moulded by national state legality and their actions in the conflict aim at a compromise between the medium-scale and the large-scale view of the conflict. For the multinational corporation, the labour conflict is a tiny accident which, if not promptly overcome, can be easily circumvented by moving the production to Taiwan or Malasia.

To analyse these discrepancies and unevennesses exclusively in terms of conflicting interests or degrees of class consciousness ignores the fact that law creates the reality that fits its application. Such creation is, among other things, a technique that operates according to certain rules, one of them being the rule of the scale. That is why we can only compare or contrast social interests and degrees of class consciousness within the same legal space. The difficulty lies in that socio-legal life is constituted by different legal spaces operating simultaneously on different scales and from different interpretive standpoints. So much is this so that in phenomenological terms and as a result of interaction and intersection among legal spaces one cannot properly speak of law and legality but rather of interlaw and interlegality. More important than the identification of the different legal orders is the tracing of the complex and changing relations among them. But if while doing this we forget the question of scale, we may find ourselves in the same distressing situation as a tourist who forgot to pack the voltage transformer that would enable him to use his electric razor in a foreign country. 
While doing my research on popular justice in the Cape Verde Islands I was confronted with an intriguing fact. The philosophy underlying the organisation of popular justice consisted in integrating local customary laws as much as possible. This integration was facilitated by the fact that the judges were lay judges, that is to say, they were members of the local communities and the written laws governing the procedures and decisions of the courts were few and vague and were often unknown to or disregarded by the judges, without any reaction on the part of the Ministry of Justice. However, both the state and the party took great care in selecting the judges and tended to favour young or middle-aged males considered politically reliable, a fact that was sometimes a source of tension in the local communities for whom the exercise of justice was in general associated with old wise folks. It would seem that while the state felt unable to control the creation of law and sought to compensate for that by tightening the control of the application of law, the local communities paid no attention whatsoever to the creation of law and sought to keep control of its application (which for them, in fact, was nothing but its creation). On further reflection, this was a case of interlegality - a case of a complex relation between the customary law and the state law using different scales. For the local communities the customary law was the local law, a large-scale legality well adapted to prevent and settle local disputes. For the state the customary law was part of a broader network of social facts that included the consolidation of the state, the unity of the state legal order, political socialisation, and so on. On this smaller scale the customary law became part of state law and the latter became an instrument, though a specific one, of political action. ${ }^{46}$

The first implication of scale conception of law is that it draws our attention to the phenomenon of interlegality and to the complex mechanics of its operation. The second implication has to do with the regulation patterns and action packages that are associated with each scale of legality. I will start by illustrating different regulation patterns. I have already mentioned the dialectical tension between representation and orientation. Indeed, we have before us two antagonistic modes of imagining and constituting reality, one geared to identify position, the other geared to identify movement. The largescale legality is rich in details and features; describes behaviour and attitudes vividly; contextualises them in their immediate surroundings; is sensitive to distinctions (and complex relations) between inside and outside, high and low, just and unjust. This applies to any social object of legal regulation, be it labour conflicts, family relations, contractual terms, crimes, or political rights. What I mean is that this form of legality favours a pattern of regulation based on (and geared to) representation and position. On the contrary, small-scale legality is poor in details and features, skeletonises behaviour and attitudes, reducing them to general types of action. But, on the other hand, it determines with accuracy the relativity of positions (the angles between people and between people and things), provides sense of direction and schemes for shortcuts and, finally, it is sensitive to distinctions (and complex relations) between 
part and whole, past and present, functional and non-functional. In sum, this form of legality favours a pattern of regulation based on (and geared to) orientation and movement.

When in 1970 I studied the informal law of the squatter settlements in Rio I had occasion to observe how adequately such local legality represented the socio-legal reality of urban marginality and how it contributed to maintain the status quo of their social positions as precarious inhabitants of shacks and houses built upon invaded land. ${ }^{47}$ When ten years later I studied the legal battles of squatter settlers in Recife who aimed at securing land tenure or, at least, a legal lease, the form of law resorted to was the state law, a smaller-scale law, that represented the socio-legal position of the squatter settlers very roughly but, on the other hand, a law that very clearly defined the relativity of their positions, the angles of their relations vis- $\dot{a}$-vis the landowners and the state, and, lastly, the shortest path to move from a precarious to a secure position under the social and political circumstances of the time. ${ }^{48}$

Besides inviting different regulation patterns, different scales of legality also condition different action packages. An action package is a connected sequence of actions structurally determined by predefined boundaries. I identify two kinds of boundaries: those defined by range and those defined by ethics. According to range, we can distinguish two ideal-types of action packages: the tactical and the strategic action package. According to ethics, we can also distinguish two ideal-types of action packages: the edifying and the instrumental action package. In the light of the previous examples I would suggest that large-scale legality invites tactical and edifying action packages, while the small-scale legality invites strategic and instrumental action packages. Social groups or classes that are predominantly socialised in one of these forms of legality tend to be specifically competent in the type of action package associated with it. In a situation of interlegality, that is, in a situation in which large-scale legality and small-scale legality intersect, the large-scale action package tends to be defensive and regulate normal, routine interaction or, at the most, molecular struggles, while the small-scale action package tends to be aggressive and to regulate critical, exceptional situations, triggered by molar struggles. ${ }^{49}$ These tendencies hold true irrespective of the class nature of the social groups involved in the specific action package.

The third and last implication of the scale analysis of the law is the least developed but potentially very important. It refers to what I would call regulation thresholds. Irrespective of the social object it regulates and the purpose of regulation, each scale of legality has a specific regulation threshold which determines what belongs to the realm of the law and what does not. This threshold is the product of the combined operation of the three thresholds: the detection threshold, the discrimination threshold, and the evaluation threshold. The detection threshold refers to the smallest details of the social object that will be considered for regulation; it distinguishes between relevant and irrelevant issues. The discrimination threshold refers to the minimum detectable differences in the description of the social object that may justify qualitative differences in regulation; it distinguishes between the same - that 
which deserves equal treatment - and the different - that which deserves unequal treatment. Finally, the evaluation threshold refers to the minimum detectable differences in the ethical quality of the social object; it distinguishes between the legal and the illegal.

During the revolutionary crisis in Portugal in 1974-75, a rural worker was indicted for the murder of a big landowner. In his defence the worker invoked provocation and a long list of arbitrary and violent actions perpetrated by the latifundiario against the rural workers during the many years in which the Salazar dictatorship allowed him to rule the community despotically. For the state legality (called then the democratic legality) the two sets of action - that of the rural worker and that of the landowner - were very different, both in structural and ethical terms. For the revolutionary legality and from the point of view of their lower discrimination and evaluation thresholds, the two sets of actions were similar in that they were both illegal. The murder could not be considered a legitimate revolutionary act but, as a reaction against the landowner's past arbitrariness, it was understandable and could be pardoned. ${ }^{50}$

The three thresholds vary according to the scale of the legal form, but the same scale of law may allow for internal differences in its regulation threshold. It may, for instance, have a high detection threshold but a low evaluation threshold or vice versa, and the discrepancies may also occur across legal realms (for instance, labour law may have a higher regulation threshold than criminal or social welfare law). Moreover, the regulation threshold is not a fixed entity. It may move up and down within certain limits. But its movement is always the result of the combined movements of the different thresholds that constitute it. In the current social and political context calling for the deregulation of the economy and social interaction, the regulation threshold moves up as a result of higher detection and discrimination thresholds. But since, in practice, the socio-legal life always involves interlegality, the deregulation in one form of legality may be counteracted or compensated for by the increase of regulation in another form of legality.

\section{Law and Projection}

Legal orders can also be distinguished by the type of projection they use. Projection is the procedure by which the legal order defines the limits of its operation and organises the legal space inside them. Like scale and for the same reasons, projection is not a neutral procedure. Different types of projections create different legal objects upon the same social objects. Each legal object favours a specific formulation of interests and a specific concept of disputes and of modes of settling them.

Each legal order stands on a grounding fact, a superfact or a supermetaphor, as I would call it, which determines the specific interpretive standpoint or perspective that characterises the adopted type of projection. The private economic relations in the market are the superfact underlying modern bourgeois legality, while land and housing, as extra-economic, social, and 
political relations, are the superfact underlying the law of the squatter settlements in Rio.

According to the type of projection adopted, each legal order has a centre and a periphery. First, this means that, as is the case with money capital, the legal capital of a given legal order is not equally distributed across the latter's legal space. The central regions are those in which the legal capital is more concentrated and owns greater profits. Here the space is mapped in greater detail and absorbs greater inputs of institutional resources (legal professions, courts, etc.) and symbolic resources (legal science, legal ideology and culture, etc.). The second implication is that conceptualisations, interpretive styles and techniques as well as ideological configurations dominant at the centre tend to be taken out of their context in which they originate and exported to (and imposed upon) the periphery. They are then applied in the legal periphery with little attention to local regulatory needs, since such needs are always interpreted and satisfied from the point of view of the centre. It is very much a symbolic transfer of technology. Sticking to my examples, it is clear that the centre of the bourgeois state legality is occupied by the contracts, as witness the codification movement and, particularly, the Napoleonic code. Contracts - their types, concepts, theories, interpretations, general principles - have been the centre of modern legislation, of modern legal training, and of modern legal ideology. Moreover, the contractual perspective has been exported to other legal fields, be they the constitutional law, the administrative law, or even the criminal law. When we hear today about the end of the contract or, in Maine's case, the return from contract to status, we should not forget that in spite of important legal developments in recent times, contracts remain the privileged archeological site and, indeed, the ground metaphor of modern law and of modern society in general. The evidence is abundant, but I will only mention, for the most recent period, the theories of the new-contractualism in political philosophy and constitutional law.

Similarly, in the informal law of the squatter settlements, land and house transactions and the disputes they originate occupy the centre of the legal space. Whenever the residents' association, acting as an informal tribunal, ventures into criminal, public order or family matters, it always seeks a connection with land and housing matters and applies to the former the popular legal technology and legal competence gained in the latter.

The centre/periphery effect of projection shows that the legal mapping of social reality is not equally distortive. It seems to become more distortive as we move from the centre to the periphery. The periphery is also the legal region where the interpenetration between different legal orders is most frequent. It creates a twilight zone where the shadows of different legal orders converge.

The second effect of projection refers to the type of features of the social object that tend to be privileged no matter how central or how peripheral the social object. According to this effect, two general types of projection can be distinguished: the egocentric and the geocentric. ${ }^{51}$ The egocentric projection favours the representation of personal and particularistic features, of voluntary or consensual social action. The geocentric projection favours the 
representation of objective and generalisable features, of patterned, bounded or conflictual social action. According to the dominant type of projection, two general forms of law can be distinguished: the egocentric legality and the geocentric legality. It is illuminating to analyse, in the light of these categories, some recent trends in legal change as well as some long-range developments in legal history as they have been described by Max Weber. While analysing in Economy and Society the forms of creation of rights, Weber drew our attention to the long and sinuous historical process by which what I call geocentric form of law gradually substituted for what I call egocentric form of law. In the past, Weber said, law arose as "volitive" and as "particularistic" law based on the agreed enactment of consensual status groups. There were different legal communities constituted in their membership by personal characteristics such as birth, political, ethnic or religious denomination, mode of life or occupation, and so on. Individuals or groups of individuals had their own personal legal quality and carried their law, their professio juris, with them wherever they went. ${ }^{52}$

The ius civile in Rome was the personal law of Roman citizens and the ius gentium was created to cover the legal needs.of non-citizens. The idea of a law of the land developed only very gradually - the lex terrae, which was applicable to everyone independent of personal characteristics and imposed as a heteronomous law within the boundaries of a given territory. In the development of a geocentric form of law, the extension of the market economy and the bureaucratisation of consensual groups played a decisive role:

The ever-increasing integration of all individual and all fact situations into one compulsory institution which today, at least, rests in principle on formal "legal equality" reached its climax in the French Revolution after which the state appears as the allembracing coercive institution. ${ }^{53}$

Max Weber was aware that in modern society there are also volitive and particularistic laws but, unlike those in pre-modern times, they are based on economic or technical grounds, are never defined in terms of personal group membership, and are effective within the boundaries set by the national general law. ${ }^{54}$

In my view, this historical interplay between geocentric and egocentric legality cannot be definitely decided in favour of geocentric legality. Some recent trends in legal development seem to witness the emergence of new legal particularisms, that is to say, forms of egocentric legality that, by creating personal legal 'enclosures', empty or neutralise the conditions for the application of the law of the land. To illustrate this I return to the new type of world legality I identified above while discussing the scale of the law. The new international commercial contracts as well as the proliferation of charters, codes of ethics, codes of conduct or of fair practices covering the activities of multinational corporations and international economic and professional associations in fields so diverse as transfers of technology, stock markets, publicity, sales promotion, market studies, insurance, technical assistance, turn-key contracts, etc. - all these new forms of world legality create a transnational legal space which often conflicts with the national state legal 
space. ${ }^{55}$ Such conflicts take several forms: the conception of liability in the new contracts is autonomous vis-à-vis national laws; the contracts introduce vague clauses on applicable law such as the general principles of law, the usages of commercial life, with the only purpose of eliminating or evading the application of the state law; the arbitration system is often resorted to with the same purpose; the commercial partners enter gentlemen's agreements or protocols that openly violate national laws (particularly those on fair competition); the national legislation enacted to police the contracts of transfer of technology has little efficacy; powerful multinational corporations impose their laws on the states. The violation of national state law is so widespread that the proposed code of ethics for multinational corporations includes the astonishing clause that "the multinational corporation will respect the laws of the state where it operates". ${ }^{56}$

All these latent or manifest conflicts are symptoms of a tension between the geocentric legality of the nation-state and the new egocentric legality of international private economic agents. Indeed, we are witnessing the emergence of a new particularism which echoes the personalistic laws of the ancient and medieval world described by Weber. Like the old status groups, each multinational corporation or international economic association has its own personal legal quality and carries its law wherever it goes. The new personalism derives also from the fact that this legality is closely tailored to the interests of the most powerful companies or banks. Goldman found that many 'standard contracts' were created by a single corporation powerful enough to impose them on its partners. ${ }^{57}$ This explains why a new economic practice by a powerful corporation may become an instant custom. This new form of status privileges (corporate privileges) can also be found in the codes of international professional associations (for example, the International Franchising Association) because in general, as Farjat noted, there is a coincidence between the powerful economic agents and the professional authorities that write the codes. ${ }^{58}$

To conceive of the tension between the nation state law and the new transnational legality as deriving from two forms of law anchored in two different types of projection of social reality prevents us from falling into a reductionist view (be it economicist or otherwise) of the conflicts they express. Truly, there are conflicting interests and power relations, but they are played out through the intermediation of specific projective devices with their own hermeneutic logic. The legal forms thus ensuing have an autonomy of their own and an efficacy that extends beyond the stakes of the conflicting interests or power positions. For instance, the attention to types of projection shows the relativity of the distinction between law and fact. Clifford Geertz recently reminded us of such relativity when different legal cultures are compared. ${ }^{59}$ But even within the same general culture the distinction between law and fact seems to be largely an effect of projection. Because of its emphasis on objective and generalisable features of reality, geocentric law tends to polarise law and fact and to be stronger on norms than on facts. Overridden by the fear of fact, it responds by sterilising or skeletonising fact. As Geertz has put it, facts 
became "close edited diagrams of reality". ${ }^{60}$ It results in "a justice of law" in Pospisil's terms. ${ }^{61}$ On the contrary, egocentric law tends to soften the distinction between law and fact and to be stronger on facts than on norms. It allows for the explosion of facts, as the case of instant customs mentioned above well documents. It results in a 'justice of fact'.

\section{Law and Symbolisation}

Symbolisation is the visible side of the representation of reality. It is the most complex procedure because it operates on the basis of and conditioned by scale and projection. Rhetoric as well as semiotics and cultural anthropology have contributed important insights into the complexities of the legal symbolisation of reality. From the synthetic perspective in which these contributions merge with that of literary criticism I shall distinguish two contrasting, ideal-typical modes of legal symbolisation: the Homeric style of law and the biblical style of law. These metaphorical designations refer to two polar, ideal-types, either of which legal orders existing in reality approximate in different degrees. The designations are borrowed from Erich Auerbach in his classical account of the different forms of representation of reality in western literature. ${ }^{62}$ Auerbach has identified two basic types of literary representation of reality in European culture. He exemplifies the opposition between these two types by contrasting the Odyssey of Homer and the Bible. The Odyssey describes the tragic and sublime nature of heroic life: a fully externalised description, uniform illumination, uninterrupted connection, all events in the foreground, displaying unmistakable meanings, few elements of historical development and of psychological perspective. On the contrary, the Bible represents the sublime and the tragic in the context of commonplace and everyday life: a description attentive to the 'multilayeredness' of the human problem in which certain parts are brought into high relief, others left obscure, multiplicity of meanings and the need for interpretation, development of the concept of the historically becoming, and preoccupation with the problematic.

In my view this basic contrast in the literary representation of reality may also be found in the legal representation of reality. Accordingly, I identify two ideal-typical sign systems by means of which law symbolises reality. I shall speak of an Homeric style of law where the legal symbolisation of reality has the following characteristics: the conversion of the everyday continuous flux of reality into a succession of disparate solemn moments (contracts, legal disputes, etc.) described in abstract and formal terms through conventional cognitive and referential signs. This style of symbolisation presupposes a form of legality that I would call instrumental legality. In contrast, what I call the biblical style of law presupposes an image-based legality characterised by a preoccupation with inscribing the discontinuities of legal interaction into the multilayered contexts in which they occur, and with describing them in figurative and informal terms, and through iconic, emotive, and expressive signs. The biblical style of law is probably older than the Homeric, but in each historical period, no matter which one dominates, there is a tension between the two. For instance, modern state legal order is predominantly an Homeric 
style of law, but the biblical style of law shows its vitality in many ways. Returning to the example of the particularistic law created by the new transnational legal subjects, it is apparent that this emerging world legality tends to be formulated in a biblical style of law. Some specialists have called attention to the moralistic rhetoric in the use of non-cognitive, emotive and expressive signs in codes of ethics and standard contracts drawn by multinational corporations and the international associations co-opted by them, as illustrated in the recurrent use of expressions like concertation, common interest, reciprocal trust, trustworthiness, co-operation, assistance, and so on. ${ }^{63}$

But the contrast between the two types of legal symbolisation is most visible in those situations of legal pluralism in which social practice is a constant bridging between legal orders with different styles of symbolisation. Somehow all of my case studies mentioned above involve situations of this type. In the case of popular justice in the Cape Verde Islands there is an attempt at a fusion between local customary law and nation-state law. The tensions between the two contrasting sign systems manifest themselves in the way judges settle the disputes. While some - generally older - judges adopt a local, image-based view of law, describing law and fact without much distinction, in figurative and informal terms, resorting to verbal and gestual signs of the iconic, expressive, and emotive type, other - and generally younger - judges seek to impersonate the professional judge or even the political cadre and, consequently, adopt an instrumental view of law distinguishing law and fact, and describing both in abstract and formal terms by resorting to verbal and gestual signs of the conventional, cognitive, and referential type. But the same judge may in different situations adopt different styles of law. Nha Bia, for instance, a remarkable woman and judge presiding over the popular court of Lem Cachorro in the outskirts of the capital city of Praia (Santiago Island) adopts a biblical style of law in those cases she is most familiar with and when she feels more autonomous to deliver justice 'in her own way'. These are, for example, the water disputes involving women - disputes usually occurring in water lines over the order of the women in the line to fill the water cans at the public fountains or over the water supply to be used daily. Since the drought often lasts several years, this is a very common type of dispute. On the other hand, Nha Bia tends to adopt an Homeric style of law whenever the dispute is less common, or in cases in which her legal competence or jurisdiction may be challenged, such as those with political overtones or involving powerful members of the community. ${ }^{64}$

In the case of the social struggles in Recife, both the urban poor and the Catholic Church on their behalf seek a momentary and unstable complementarity between the unofficial law of the squatter settlements and the state official law. The construction or imagining of reality in the two legal orders follows different sign systems, the biblical and the Homeric style respectively. Community leaders and lawyers hired by the Church to represent the urban poor often find themselves in the position of having to translate one sign system into the other before the relevant audience of the moment - whether 
the audience is the people from the community, the state court, or the state administrative agency for housing matters. It may also occur that the two sign systems interpenetrate or superimpose, as when large groups of squatter settlers attending the trial of one of the land disputes in the state court start shouting slogans and singing religious songs. ${ }^{65}$

In the case of popular justice during the revolutionary crisis in Portugal there is neither an attempted complementarity nor fusion but rather an open contradiction between two forms of law - in this case between democratic legality and revolutionary legality. The democratic legality tries to insulate the legal representation of reality from the everyday experience of a revolutionary crisis and for that purpose it stresses the distinction between law and fact and resorts to a formal and abstract description of reality in which the sign system characteristic of an Homeric style of law dominates. On the contrary, the revolutionary legality tries to integrate and even dissolve the legal representation into the social and political context in which it occurs, and for that purpose it softens the distinction between law and fact, thus allowing for the explosion of facts as a mechanism of law creation, and privileges a figurative and informal description of reality. ${ }^{66}$ In sum, it is a biblical style of law.

\section{TOWARD A POSTMODERN CONCEPTION OF LAW}

Chaim Perelman has written in his treatise on the new rhetoric that while classical thought favoured spatial metaphors, modern thought has favoured temporal ones. ${ }^{67}$ It seems to me that postmodern thought will return to spatial metaphors, even though inspired by new spaces and spatialities. It is not surprising that postmodernism started as a debate within architecture, the art of space created by people. ${ }^{68}$ The theory of a symbolic cartography of law sketched here may be considered a sociological attempt toward a postmodern conception of law.

Scale, projection and symbolisation are not neutral procedures. The choices made within each of them promote the expression of certain types of interests and disputes and suppress that of others. The autonomy of law as a specific way of representing, distorting, and imagining reality derives from the operation of these procedures. Since this symbolic cartography of law does not explain why the choices in the operation of these procedures are made, it may be viewed as relapsing into analytical formalism. However, our century has been too much overridden by the opposition between the formal and the informal, both concerning social action and scientific analysis. ${ }^{69}$ Now, as we are approaching the end of the century, it is time to see the formal in the informal and the informal in the formal. At the level of the sociological analysis of law such a relational view is best obtained once we conceive of law in legal pluralistic terms.

Legal pluralism is the key concept in a postmodern view of law. Not the legal pluralism of traditional legal anthropology in which the different legal orders are conceived as separate entities coexisting in the same political space, but rather the conception of different legal spaces superimposed, interpenetrated, 
and mixed in our minds as much as in our actions, in occasions of qualitative leaps or sweeping crises in our life trajectories as well as in the dull routine of eventless everyday life. We live in a time of porous legality or of legal porosity, of multiple networks of legal orders forcing us to constant transitions and trespassings. Our legal life is constituted by an intersection of different legal orders, that is, by interlegality. Interlegality is the phenomenological counterpart of legal pluralism and that is why it is the second key concept of a postmodern conception of law.

Interlegality is a highly dynamic process because the different legal spaces are non-synchronic and thus result in uneven and unstable mixings of legal codes (codes in a semiotic sense). The mixing of codes is visible in all the case studies I mentioned. It is also visible in the ways in which the emerging world legal space appropriates local legal vernaculars. As I have demonstrated, the small-scale world legality mixes the telescopic view of reality with a moralistic rhetoric typical of large-scale legality. While broadening the legal space to a world or even planetarian scale it creates new particularisms and new personalisms, echoing the medieval privileges of the different professiones juris. The mixing of codes is still visible in the popular images of law. In a recent study Stewart Macaulay has shown how the mass media and particularly the television promote a fragmented and inconsistent view of law

a view of overlapping and contradictory legal messages, of rules and offsetting counterrules inciting both to obedience and to disobedience, to legal and illegal action. ${ }^{70}$

Such a conception of legal pluralism and interlegality calls for complex analytical tools. Those presented here aim to show that the fragmentation of legality is not chaotic. It is a social construction built according to the rules of scale, projection, and symbolisation. In a polycentric legal world the centrality of the state law, though increasingly shaken, is still a decisive political factor. But above all it is reproduced by multiple mechanisms of acculturation and socialisation. As there is a literary canon that establishes what is and what is not literature, there is also a legal canon that establishes what is and what is not law. Because people are permanently (even if inconsistently) socialised and acculturated in the types of scale, projection, and symbolisation that are characteristic of the national state legal order, they refuse to recognise as legal those normative orders that use different scales, projections, and symbolisations. They are beyond the minimum and the maximum threshold of legal cognition. Some (infra-state, local) legal orders are too close to everyday reality to be viewed as a fact of law (a legal fact). Other (supra-state, world) legal orders are too remote from everyday reality to be viewed as a law of fact (a legal fact). The symbolic cartography of law using as a metaphor such commonplace and vulgar objects as maps contributes to the creation of a new legal common sense which is the third key concept of a postmodern conception of law. ${ }^{11}$ Modern scientific knowledge has been constructed in total insulation from common-sense knowledge and in opposition to it. A postmodern science is distant enough from common-sense knowledge to be able to refuse the existing common sense, but sufficiently close to conceive the creation of a new 
common sense as its sole objective..$^{72}$ As far as law is concerned, the new common sense will be a legal pluralistic common sense.

To achieve such a goal the sociology of law must change its priorities: instead of engaging exclusively in the critique of the existing state legality it must also uncover the latent or suppressed forms of legality in which more insidious and damaging forms of social and personal oppression frequently occur. Thus conceived, the sociology of law will become an edifying knowledge that, by enlarging and deepening our legal vistas, will contribute towards a radical democratisation of social and personal life. ${ }^{73}$ Only then will law be an unqualified human good. ${ }^{74}$

To conclude, I shall go back to my starting point. This conception of law and of sociology of law shows that we are not yet definitely condemned to the 'camelisation' of law and that Nietzsche might graciously grant us a fourth metamorphosis. In such a case we may ask which animal will take the place of the camel that took the place of the lion that took the place of the child. In view of the emphasis put by the postmodern conception of law on legal pluralism, interlegality, mixing of codes, and non-synchronism, I dare to suggest that this animal will be the chameleon. By constantly changing its colours according to certain biological rules, the chameleon is truly not an animal but rather a network of animals - as much as law is a network of legal orders. Law as a chameleon may turn out to fit the postmodern conception of law.

\section{NOTES AND REFERENCES}

1 F. Nietzsche, "Thus Spoke Zarathustra" in The Portable Nietzsche (1982; ed. W. Kaufmann) p. 137.

2 J. Habermas, Theorie des Kommunikativen Handelns (2nd ed. 1982) Vol, 2, p.489.

3 P. Nonet and P. Selznick, Law and Society in Transition: Toward Responsive Law (1978).

4 G. Teubner, "Substantive and Reflexive Elements in Modern Law" (1983) 17 Law and Society Rev. p. 239.

5 T. O'Hagan, The End of Law? (1984).

6 M. Foucault, La Volonté de Savoir (1976); Discipline and Punish (1977); Power and Knowledge (1980).

7 R. Abel, "Redirecting Social Studies of Law" (1980) 14 Law and Society Rev. p. 826.

8 Id.

9 D. Nelken, "Beyond the Study of 'Law and Society": Henry's Private Justice and O'Hagan's The End of Law?" (1986) American Bar Foundation Research J. See, J. Griffiths, "What is Legal Pluralism?" (1986) 24 J. of Legal Pluralism p. 1.

11 A. Hunt, "The Critique of Law: What is 'Critical' about Critical Legal Theory?" (1987) 14 J. of Law and Society p. 13.

12 S. Henry, Private Justice (1983).

13 B. Santos, "On Modes of Production of Social Power and Law" (1985) 13 International J. of Sociology of Law p. 299.

14 H. Bloom, A Map of Misreading (1975).

15 J. L. Borges, Dreamtigers (1970) p. 90.

16 M. Monmonier, Maps, Distortion, and Meaning (1981) p. 1.

17 See, A. G. Hodgkiss, Understanding Maps. A Systematic History of their Use and Development (1981) p. 103. In the sixteenth century Mercator, the famous Flemish geographer who developed the type of maps projections which now bears his name, wrote 
the following instruction on his famous chart of 1569: "If you wish to sail from one port to another, here is a chart, and a straight line on it, and if you follow carefully this line you will certainly arrive at your port of destination. But the length of the line may not be correct. You may get there sooner or you may not get there as soon as you expected, but you will certainly get there." Quoted from W. W. Jervis, The World in Maps. A Study of Map Evolution (1936) p. 27.

18 F. Wahl, "Le Désir d'Espace" in Cartes et Figures de la Terre (1980; ed. Centre Georges Pompidou) p. 42.

19 Josef Konvitz, "Remplir la Carte" in Cartes et Figures de la Terre, op. cit., n. 18, p. 314. On maps as the fundamental analogy, see A. Robinson and B. Petchnik, The Nature of Maps: Essays Toward Understanding Maps and Mapping (1976) p. 2. Monmonier, op. cit., n. 16, p. 4.

Id. J. S. Keates, Understanding Maps (1982) p. 73.

M. Monmonier, op. cit., n. 16, p. 4.

P. C. Muehrcke, Map Use (2nd ed. 1986) p. 10. M. Monmonier, op. cit., n. 16, p. 4.

26 See, Y. Lacoste, La Géographie, ça sert, d'abord, à faire la guerre (1976) p. 61; Y. Lacoste, "Les objets géographiques" in Cartes et Figures de la Terre, op.cit., n. 18, p. 17.

27 See, J. B. Racine et al., "Escala e acção, contribuições para uma interpretação do mecanismo de escala na prática da geografia" (1982) 45 Revista Brasileira de Geografia p. 126.

28 See, among others, M. Monmonier, op. cit., n. 16, p. 15; J. S. Keates, op. cit., n. 22, p. 72; P. C. Muehrcke, op. cit., n. 24, p. 456; D. Muracciole, "Le rond et le plat" in Cartes et Figures de la Terre, op. cit., n. 18, p. 235; A. G. Hodgkiss, op. cit., n. 17, p. 32.

29 On the use of maps for propaganda purposes, see M. Monmonier, op. cit., n. 16, p. 43; A. G. Hodgkiss, op. cit., n. 17, p. 15; P. C. Muehrcke, op. cit., n. 24, p. 395; J.-L. Rivière, "Cartes Polémiques" in Cartes et Figures de la Terre, op. cit., n. 18, p. 351; H. Speier, "Magic Geography" (1941) 8 Social Research p. 310; L. Quam, "The Use of Maps in Propaganda" (1943) 42 J. of Geography p. 21; S. W. Boggs, "Cartohypnosis" (1947) 64 Scientific Monthly p. 469; M. Sharkey, "Cartography in Advertising" (1984) 22 The Cartographical J. p. 148.

30 See, A. Hodgkiss, op. cit., n. 17, p. 29. For a slightly different view, showing the way the map centre changed as the Middle Ages developed, see D. Woodward, "Reality, Symbolism, Time, and Space in Medieval World Maps" (1985) 75 Annals of the Association of American Geographers p. 510. A. Henrikson, in "America's Changing Place in the World: from 'Periphery' to 'Centre'?" in Centre and Periphery: Spatial Variation in Politics (1980; ed. J. Gottmann) p. 73, shows how the progressive shift of the U.S.A. from the periphery to the centre of world affairs - a shift completed with the Second World War - resulted in changes in the types of map projections adopted or favoured: "The relationship of the United States to the major theatres of battle was such that a new picture of the world - a new global strategic map - was needed. Cylindrical maps projections, such as the conventional Equator-based Mercator, failed to show the continuity, unity, and organisation of the 'world wide arena' as Roosevelt called it. Hence, other map projections came into fashion, notably the North Pole-centred azimuthal projection. .. . The position of the United States on these polar maps was usually a central one." (p. 83). See also, A. Henrikson, "The Map as an 'Idea': The Role of Cartographic Imagery During the Second World War" (1975) 2 The American Cartographer p. 19.

31 P. Muehrcke, op. cit., n. 24, p. 6.

32 L. Carroll, "The Hunting of the Snark" in Complete Works (1976) p. 757.

33 Id., p. 760.

34 J. S. Keates, op. cit., n. 22, p. 66.

35 M. Monmonier, op. cit., n. 16,.p. 6.

36 See, R. Caron, "Les Choix de Cartographe" in Cartes et Figures de la Terre, op. cit., n. 18, p. 9.

37 See, J. S. Keates, op. cit., n. 22, p. 69. 
C. Geertz, Local Knowledge (1983) p. 232.

C. Perelman, The New' Rhetoric: A Treatise in Argumentation (1971) p. 405.

B. Santos, "Law and Revolution in Portugal: the Experiences of Popular Justice after the 25th of April 1974" in The Politics of Informal Justice (1982; ed. R. Abel) Vol. 2, p. 251; B. Santos, "A Crise do Estado e a Aliança Povo/MFA em 1974-75" in 25 de Abril-10 Anos Depois (1985; ed. Associação 25 de Abril) p. 45; B. Santos, "Popular Justice, Dual Power and Socialist Strategy" in Capitalism and the Rule of Law (1979; ed. B. Fine et al.) p. 151 .

B. Santos, "Law, State and Urban Struggles in Recife, Brazil" (1982) University of Wisconsin-Madison Law' School Working Paper. See also, B. Santos, "Os conflitos Urbanos no Recife: o caso do 'Skylab' " (1983) 11 Revista Crítica de Ciências Sociais p. 9; B. Santos, "The Law of the Oppressed: The Construction and Reproduction of Legality in Pasargada Law" (1977) 12 Law and Society Rev. p. 5.

B. Santos, A Justiça Popular em Cabo Verde. Estudo Sociológico (1984; ed. Centro de Estudos Sociais, Faculdade de Economia da Universidade de Coimbra).

See, P. Kahn, "Droit International économique, droit du développement, lex mercatoria; concept unique ou pluralisme des ordres juridiques?" in Le Droit des Relations Economiques Internationales (1982; ed. P. Fouchard et al.) p. 97. See all the other articles in the same book. See also, C. D. Wallace, Legal Control of the Multinational Enterprise (1982).

44 See, G. Farjat, "Reflexions sur les codes de conduite privés" in Droit des Relations Economiques Internationales, op. cit., n. 43, p. 47.

4 For an in-depth analysis of the economic and legal nature of subcontracting both in general and in the Portuguese context, see M. M. Marques, "Regulação das relações entre empresas: o caso da subcontrataçào" in Estudos Económicos e Juridicos (1986; ed. Faculdade de Economia da Universidade de Coimbra) p. 247; M. M. Marques, "A empresa, o espaço e o direito" (1987) 22 Revista Critica de Ciências Sociais p. 69.

See, B. Santos, op. cit., n. 42, p. 33.

See, B. Santos, "The Law of the Oppressed", op. cit., n. 41, p. 38.

See, B. Santos, "Law, State and Urban Struggles", op. cit., n. 41 and "Os conflitos urbanos", op. cit., n. 41.

For the distinction between molar and molecular struggles, see G. A. Miller et al., "Plans" in Culture and Cognition (1972; ed. J. P. Spradley) p. 52 at p. 59.

See, B. Santos, "Law and Revolution", op. cit., n. 40, p. 272.

This distinction is also used, in a slightly different sense, in the analysis of cognitive mapping (egocentric and geocentric mental maps). See, P. C. Muehrcke, op. cit., n. 24, p. 4.

See, M. Weber, Economy and Society (1978) p. 695.

Id., pp. 698 and 724.

Id., p. 697.

On the new transnational legal space and its conflicts with the national legal space, see the authors cited in footnotes 43,44 and 45.

See, Destanne de Bernis cited in G. Farjat, op. cit., n. 44, p. 65.

See, B. Goldman, "Frontières du droit et lex mercatoria" (1964) IX Archives de Philosophie du Droit p. 180.

See, G. Farjat, op. cit., n. 44, p. 57.

See, C. Geertz, op. cit., n. 38, p. 167.

Id., p. 173.

L. Pospisil, Anthropology of Law: A Comparative Theory (1971) p. 23.

E. Auerbach, Mimesis. The Representation of Reality in Western Literature (1968) p. 23.

See, for instance, G. Farjat, op. cit., n. 44, p. 65.

See, B. Santos, op. cit., n. 41, p. 105.

See, B. Santos, "Law, State and Urban Struggles", op. cit., n. 41, p. 21.

See, B. Santos, "Law and Revolution, op. cit., n. 40, p. 254.

C. Perelman, op. cit., n. 39, p. 390.

See, among others, F. Jameson, "Postmodernism, or the Cultural Logic of Late Capitalism" (1984) 146 New Left Rev. p. 53. 
69 See a fascinating analysis of law and informalism in P. Fitzpatrick, "The Rise and Rise of Informalism" in Reconstructing Criminal Justice (forthcoming; ed. R. Matthews). See also, U. Cerroni, "Formale e Informale" (1986) 23-24 Scienzasocietá p. 3.

10 S. Macaulay, "Images of Law in Everyday Life: The Lessons of School, Entertainment and Spectator Sports" (1987) 21 Law and Society Rev. p. 185.

$"$ On the vulgar and trivial nature of our daily encounters with maps, see A. G. Hodgkiss, op. cit., n. 17, p. 11: "It is difficult to avoid being confronted by at least one or two maps during the daily routine. Perusing the morning paper in the commuter train we are likely to see small black-and-white maps serving to locate and explain some significant contemporary event. At home in the evening similar maps face us on the television screen, as a feature of the television news. The current state of the weather is indicated in the press and on television with the aid of satellite photographs and maps which have been specially designed so that their meaning should be clear to the unt rained map user." The new legal common sense aims at trivialising our daily encounters with the laws so that their meaning becomes clear to the untrained law user.

12 See, B. Santos, Um Discurso Sobre as Ciências (1987).

13 On the possibility of an edifying knowledge, see R. Rorty, Philosophy and the Mirror of Nature (1980) p. 373.

14 And not before that, as E. P. Thompson claims. See, E. P. Thompson, Whigs and Hunters (1975) p. 258. 